\title{
Factors and Steps for Successful Transition from a State of Making to One of Innovating
}

\author{
Jeffrey Yi-Lin Forrest ${ }^{1, *(1)}$ and Zaiwu Gong ${ }^{2}$ (D) \\ 1 School of Business, Pennsylvania State System of Higher Education (Slippery Rock campus), 1 Morrow Way, \\ Slippery Rock, PA 16057, USA \\ 2 Institute of Management Science and Technology, College of Management Science and Engineering, \\ Nanjing University of Information Science and Technology, Nanjing 210044, China \\ * Correspondence: jeffrey.forrest@sru.edu; Tel.: +1-724-738-2510
}

Received: 29 July 2019; Accepted: 1 August 2019; Published: 3 August 2019

\begin{abstract}
Other than serving as the introduction to this special issue, this paper looks at the question of how an underdeveloped or a developing economic entity can manage to acquire the knowledge and ability to overcome various barriers, be they social, cultural, or institutional, to establish its desired momentum of self-sustained growth. It addresses the question by surveying relevant literatures, first, about what factors, both internal and external, positively determine the innovativeness of an economic entity; and second, regarding what steps are necessary for an underdeveloped or a developing entity to engineer its momentum of self-sustained growth and for an established entity to maintain its existing momentum. By doing so, we demonstrate the theoretical significance and practical importance of this issue and the works contained in this issue.
\end{abstract}

Keywords: ambition; innovation; mission; manufacturing; self-sustained growth

\section{Introduction}

As the nation that has been growing at an unprecedented high rate in the past four decades, China has become the second-largest economic power of the world. In this process of fast development, China has been the largest manufacturing nation in the world, although not the strongest. Currently, China faces internal pressures, such as economic downturn, insufficient scientific and technological innovation, low energy efficiency, serious environmental pollution, and rising labor costs [1]. At the same time, it is under great economic and political pressure from the international world of business, such as the current trade conflicts with the United States of America [2,3]. In other words, as an economic entity, China confronts serious challenges both internally and externally. For of this reason, China provides the world of learning a great opportunity to investigate the following question: How can an underdeveloped and/or developing nation manage to acquire the knowledge and ability to overcome its various barriers, be they social, cultural, or institutional, in order to institute its desired momentum of self-sustained development?

Answers to this question will not be unique while they are all very important, just as economic historian Gregory Clark [4] describes regarding what triggered the English Industrial Revolution in the 18th century: "Explaining the Industrial Revolution is the ultimate, elusive prize in economic history. It is a prize that has inspired generations of scholars to lifetimes of, so far, fruitless pursuit." However, the large body of relevant literature suggests that developing a self-sustaining momentum of economic development seems to be a mysterious process of dramatic socioeconomic changes. Other than the few Western countries, all the aspiring developing nations have failed miserably and repeatedly throughout the modern history of the past one hundred plus years, although they longed to emulate such a process. 
To this end, the matter of fact is that the world of learning is still struggling to comprehend the process and to identify its ultimate causes [4-16].

Aiming at the potential of addressing the question posed above, we launched this special issue of the international journal 'Sustainability' in order for the world of learning to look at the current state of China's economy from different angles. We hope that the articles included in this issue are able to provide some useful and thought-provoking insights for policy makers, for entrepreneurs, and for investors, while playing the role of record keeping for future historians.

For the sake of convenience of communication, in this article, we treat an economic agent, a business firm, an economic organization, or a nation, all as a system, known as an economic entity. The justification for doing so is the fact that, systemically speaking, all systems share the same yoyo structure [17].

Because innovation is commonly recognized as the key for an economic entity to evolve from reactively manufacturing elementary products to innovatively producing epoch-making devices [18] and is an essential factor that underlies the competitiveness, productivity, output, and employment performance of nations [19], we name this special issue "Transition from China-Made to China-Innovation." Here for the general purpose of scholarly investigation, the word 'China' can be replaced by the name of any specific nation that is of concern, and the rest of this presentation wraps around the concept of innovation.

The rest of this article is organized as follows: Section 2 looks at environmental factors that potentially help transform a manufacturing giant into an innovative power. In this section, we also look at the concept of innovation in manufacturing. Section 3 considers internal forces that underlie manufacturing innovativeness. Section 4 presents practical procedures for either an underdeveloped or a developing economic entity to engineer its momentum of self-sustained growth and for an established entity to maintain and to develop further its existing momentum. Section 5 concludes this presentation.

\section{Environmental Factors That Potentially Transform a Manufacturing Giant into an Innovative Power}

Since 1776 when Adam Smith published his monumental work, The Wealth of Nations, the importance of innovation has been recognized as a crucial activity that fosters wealth. Innovation stands for a fundamental belief and attitude that are under each competitive advantage with innovativeness closely related to the prosperity of any manufacturing nation [20]. This explains why it is inescapable for China to think about and plan for its transition from the current state of China made to the ideal state of China innovation [21]. More specifically, innovation works through introducing original products and processes [22] that enable China, like a manufacturing firm, to competitively enter or create new markets [23].

In terms of what has been established, the issues we attempt to address fit the literature of innovation in the manufacturing sector perfectly. For example, Veugelers and Cassiman [24] examine innovation strategies. Amara and Landry [25] study how sources of information play a role on the novelty of innovation. Becheikh et al. [22] demonstrate that product and process innovations are closely associated with the manufacturing environment with product innovation receiving more attention from scholars and managers. Nieto and Santamaria [26] investigate the critical factors behind product innovations by looking at the role of diverse types of collaborative networks. Alegre and Chiva [27] study how organizational learning capability affects product innovation performance. Lin et al. [28] explore the increasing importance of green products and whether and how green product innovation can affect firm performance. Caputo et al. [29], Buffington [30], and Zollo et al. [31] look at how the environment of manufacturing has been changed drastically by the recent economic globalization and the advent of internet-based technologies, leading to remote manufacturing, computer-integrated manufacturing systems, Internet-based manufacturing, and more. Roos [32] and Wu et al. [33] investigate how these new modes of manufacturing have redefined the concept of innovation in manufacturing. 


\subsection{Innovation in Manufacturing}

Schumpeter [34] discusses the concept of innovation within the context of a firm by delineating its extent as product, process, and business model. He later [35] references the concept of innovation processes. Manifesting the importance of Schumpeter's works, an extensive literature of empirical evidence on innovation emerges [36-38] that provides information for companies to develop a competitive advantage or to gain entry into new markets [39-41].

The concept of innovation in manufacturing has been formulated by various authors, such as Pittaway et al. [42] from the angle of necessity and sufficiency, Lansisalmi et al. [43] from that of intentionality, Camison-Zornoza et al. [44] from that of beneficial nature, Hobday [45] from that of practical implementation, and Peres et al. [46] from that of its diffusion. Because innovation is a phenomenon that is wide ranging and multifaceted, several different definitions have been introduced in the literature, e.g., [22,40,47]. For our purposes, let us adopt the definition of the concept introduced by [8] as follows:

Innovation in manufacturing is such a collection of activities that leads to exceptionally added value to an economic entity (such as a company or a nation) when compared to other activities that take place in the same manufacturing area.

Because of the emphasis on comparatively added value, this definition implies many facets of innovation. For example, 'exceptionally added value' means (1) an extraordinary level/quality of creativity; (2) internal conception and external adoption of the creativity; (3) introduction of new processes for capturing value; (4) materialization of benefits; (5) transformation of inventions into products and/or processes; and (6) potential roles played by relevant processes and outcomes. Beyond all these significant implications, this definition does not include those innovations that merely keep an economic entity afloat compared to others in the same industries. In other words, the urge for an economic entity to innovate is mainly from within the entity; and such an urge is expressed in the entity's mission statement [48]. For more in-depth discussion, see [8].

As for the question of how markets stimulate innovation, the following result is shown by Zhao et al. [49]. In other words, market demands invite economic entities to compete through innovation.

Theorem 1. A nation's product can profitably enter the world market described below, as a competitor of the incumbent nations, if, and only if, the market percentage of switchers, $\beta$, satisfies $\beta=1-\alpha>0$, where the market satisfies the following conditions:

- It is occupied by m nations, $m=1,2, \ldots$, serving mutually substitutable products;

- Each incumbent nation has its loyal customers who purchase only the product of their favorite nation if the price is no more than their reservation value with $\alpha$ being the market percentage of all loyal customers of the incumbent nations;

- The incumbent nations compete over the market segment, $\beta$, of those customers who switch from the product of one nation to another depending on whose price is more competitive; and

- These nations are well aware of the pricing strategies of each other. They establish their best responses by playing the Nash equilibrium through pure self-analyses.

\subsection{Environmental Factors That Positively Affect an Economic Entity's Innovativeness}

Since the 1960s, nearly 20 environmental determinants of manufacturing innovation have been identified [22]. These determinants are classified into six categories-industry, region, culture, networking, knowledge and technologies, and international) trade policies (such as those of the government and public sector, if we focus on individual firms instead of nations).

Within the category of 'industry', there are such determinants as 'technological dynamism' [50-52], 'demand growth' [53-55], and 'industry structure' [56-59]. Within the category of 'region', there are such determinants as 'location' [60] and 'proximity" advantage [61]. Within the category of 'culture', 
there are such determinants as 'external financial support' [62,63], 'power distance', 'risk avoidance', 'femininity-masculinity', 'collectivism-individualism', and 'temporal orientation' [64-67].

Within the category of 'networking', there are various interactions with different stakeholders, such as universities, research centers, industrial and professional associations, consultants, service providers, suppliers, and consumers [61,63,68-70]. The category of 'knowledge and technologies' deals with 'how knowledge/technology is acquired' by an economic entity, consisting of both formal and informal acquisitions and taking various forms. These forms include purchase of equipment, licenses, and sponsorship agreements; attendance of conferences and specialized fairs; or simply the informal exchanges with various actors in the economic entity's environment [70-72]. The category of '(international) trade policies', under which an economic entity operates, affects the innovativeness of the entity [73,74].

By employing systems thinking, Forrest et al. [75] demonstrate that among these twenty or so environmental determinants of an economic entity's innovativeness in manufacturing, only the following four are primary-'demand growth', 'proximity', 'networking', and '(international) trade policies'. All other determinants, empirically identified in the literature, are secondary; they appear naturally as consequences of the primary determinants.

\section{Internal Forces That Underlie Manufacturing Innovativeness}

This section glances through the nearly forty internal factors empirically identified in the literature and tries to pinpoint those that are primary and underlie the manufacturing innovativeness of an economic entity. This section consists of two subsections. The first one looks at strategic factors, while the second one addresses organizational factors.

\subsection{Strategic Factors That Positively Affect an Economic Entity's Innovativeness}

The question of what main strategic tactics primarily underlie the innovative activities of manufacturing is both practically significant and theoretical valuable. This is because innovation is a crucial economic activity that fosters wealth [18], unavoidable for each company that wants to develop and maintain a competitive advantage [76] and an essential factor underlying the competitiveness, productivity, output, and employment performance of any nation [19]. Because of this, the literature has empirically identified sixteen strategy-related factors that positively affect the innovativeness of manufacturing.

In terms of global strategies on innovation, empirically identified ones include a 'clearly defined strategy' [77], 'corporate diversification strategy' [71,78,79], and 'market-territory strategy' [61,70]. Regarding growth strategies, the literature considers the following three: 'Differentiation strategy' [55, 58,59,80], 'cost reduction strategy' [55,81], and 'protection mechanism' [24,82].

In the name of operational strategies, scholars studied the following variables:

- 'R\&D assets and strategies' $[58,63,83,84]$,

- 'Monitoring of competitors' [85],

- 'Marketing strategies' [77],

- 'Personnel qualification/experience' [86,87],

- 'HR strategies' [50],

- 'Advanced equipment/technologies' [57,88],

- 'Degree of capacity utilization' [61],

- 'Financial autonomy' [59],

- 'Turnover/profit' [77], and

- 'Budget/funds availability' $[59,77]$.

By going beyond the empirical approach, Forrest et al. [89] employ systems methodology to produce the following results: 
- In manufacturing, a clearly defined strategic orientation is positively correlated to innovativeness.

- For the corporate diversification strategy, if the word 'diversification' is understood as simultaneously reaching into different markets with different lines of products, then efforts for such diversification would tear the technological integrity, the labor force, and available resources of the company into pieces. Therefore, such a diversification strategy is not encouraged.

- If "diversification' means increasing functionalities of existing products to make them satisfy the needs and likings of customers from diverse markets, then pushing for diversification will support the innovativeness of manufacturing.

- In terms of the market-territory strategy, economic entities involved in import-export trades are expected to be most innovative, followed by those that only import, then those that only export, and finally those that stay $100 \%$ domestic.

- The 'differentiation strategy' is a dominating determinant on innovation, while all operational strategies are secondary when compared to the mission and global strategies of the firm.

\subsection{Organizational Factors That Positively Affect an Economic Entity's Innovativeness}

This subsection looks at how culture, organizational structure, and leadership affect the manufacturing innovativeness of an economic entity. Beyond recognizing the importance of innovation in terms of wealth creation [18], the currently increasing greatness of competition of the world economy also makes innovation an unavoidable issue for each economic entity to consider [76]. Considering the fact that culture, organizational structure, and leadership represent some of the most essential aspects of any economic entity, the issue this subsection looks at is quite urgent for both theoretical and practical purposes. Because of this, many scholars in the past decades have empirically checked the effects of various factors related to culture, structure, and leadership on the innovativeness of manufacturing.

In terms of culture, Forrest et al. [90] developed a general theory on how individual and organizational philosophical and value systems are formed. On top of this theory, these authors investigate what organizational culture symbolizes, and why, for each organization, mission and ambition represent two forces that unify inconsistencies existing in individuals' philosophical assumptions and values. As consequences of such discussions, they establish the following general conclusions by carrying earlier empirical discoveries $[24,85,87,91,92]$ to the height of theory so that general recommendations can be derived for practical purposes:

- For an economic entity, its culture significantly determines its innovativeness;

- Total quality management is a realization of the culture of continuous improvement within an economic entity. It is a real-life implementation of the entity's business ambition;

- Resistance to change is negatively correlated to innovativeness; and

- Support for innovation is a perception that is positively correlated to innovativeness.

Regarding the effects of leadership on innovativeness, the literature has considered such variables as 'presence of a project leader' [77,93], 'CEO's characteristics' [92], 'CEO change' [48], and 'CEO's qualification and experience' [94]. By employing systems methodology, Forrest et al. [90] conclude that all these variables are secondary when compared to having a long-term, unwavering ambition.

In terms of an economic entity's general characteristics and its innovativeness, the literature empirically identified such variables as 'size of the entity' [76,95,96], 'age of the entity' [88,97], 'ownership structure' [54,72], and 'past performance' [55,96]. Through careful analysis, Forrest et al. [90] find that none of these general characteristics are primary determinants of innovativeness in manufacturing when compared to the mission and global strategies of the economic entity.

Regarding the effects of an economic entity's structure on its innovativeness, the literature considers such variables as 'formal structure' [98], 'flexible structure' [67,99], 'centralization of decision making' [100], 'empowerment of employees' [67,101], and 'interaction between firm's units' [102,103]. Based on systemic reasoning, Forrest et al. [90] derive the conclusion that these variables are all secondary and are the consequences of practical implementations of the long-term, unwavering ambition. 


\subsection{Managerial Recommendations}

This subsection looks at what the previous two sections imply for managers and policy makers in terms of making their economic entity more innovation oriented.

First, at the managerial level, promoting innovativeness begins with an inventive understanding of market signals and the prevalent trade policies, followed accordingly by aligning an economic entity's strategies to develop its distinctive competencies and by possibly going beyond the existing market territory to generate additional demand. The factor 'proximity' of innovation needs to be materialized in different ways, such as conducting R\&D activities near centers of information and knowledge, sales efforts having easy access to consumers, production being conveniently reachable by suppliers, or the distribution of business units stimulating cooperation with partners. In addition, at the policy-making level, fostering innovation in manufacturing needs to purposefully encourage market competition by removing entry barriers, preventing monopoly, assisting with market-territory expansion, and providing financial support and necessary infrastructure.

Second, leaders of an economic entity need to have a clearly stated mission and long-term, unwavering ambition, representing the most important and unifying forces for the appearance of desired innovativeness. By clearly demonstrating its commitment to the mission and ambition, the leadership cultivates an organizational culture conducive to change, innovative activities, and the realization of the ambition. The next step in promoting innovativeness is to clearly define the strategies on how to actualize the mission and ambition, while paying attention to the following:

- For diversification, the focus needs to be on continuously improving the functionalities of products and involving in import-export trades for the purpose of expanding markets.

- For developing alliances, the focus needs to be on the learning and introduction of new technologies while avoiding disruptions to established routines.

- For growth, the emphasis is on building differentiations on distinctive strengths by, for example, establishing special task force(s) to identify market signals and reactions, developing newer/better differentiations instead of spending too much on protection, and minimizing costs through innovatively developing efficient production processes and operational routines.

- At operational level, secondary strategic steps are encouraged, including R\&D activities, recruiting/maintaining qualified and experienced personnel backed with advanced technologies, conducting regular continuous improvement and retraining programs for all employees, applying effective marketing, monitoring competitors and customers' evolving desires, and ensuring the financial solvency of the economic entity by avoiding excessive debts.

Third, central to the realization of the established mission and ambition, leaders of all levels need to possess specific characteristics, such as emotional steadiness; perceptive aptitudes to imagine the future; business knowledge; scorching desires, energies, and tenacities; and initiatives to achieve, lead, and rally supports. The next step in promoting innovativeness is to develop a flexible administrative structure for the economic entity of concern so that the decision-making process efficiently facilitates concentration of efforts and resources on survival and growth. For a large, well-established economic entity, decision-making should be decentralized to promote the innovativeness of each division while empowering and encouraging employees of different divisions to interact. Operationally, the economic entity needs to pay attention to the maintenance of such secondary determinants of innovativeness as 'firm size' and good 'performance'. Here, personnel decisions need to be in harmony with changing market demands, however, good performance is generally good for investors and a good indicator of quality of the economic entity.

\section{Engineer Momentum of Self-Sustained Growth}

With the knowledge of what environmental and internal factors underlie the innovativeness of manufacturing, a consequent natural question is how an economic entity can position itself on a track of sustaining growth, which, of course, has to be innovation based as the literature suggests. 
Being able to answer this question practically has been the dream of many business firms [104] and developing countries in the past one hundred plus years [9]. However, this practical demand was not adequately met by the studies in mainstream economics until Forrest et al. [8] systemically investigated this question and provided a procedure applicable in real life.

Momentum of self-sustained growth, means a self-sustained movement in which new and advanced technologies are constantly introduced, making the way people live continuously improved [105]. For an established entity, it means how to continue and further improve the current state of affairs into the future, while for a developing nation it indirectly means industrialization and modernization. Developing such a momentum turns out to be a process that revolutionizes the mode of production at all different levels and an endeavor that develops and strengthens the economic entity of concern [8]. This process unprecedentedly coordinates all social classes and interest groups and mobilizes all kinds of resources in ways never seen before. The progression of such a process strengthens the underlying economic entity in terms of organizational consolidation, prosperity, and logistic capacity of projecting influences, be they economic, cultural, political, or others.

Since the late 18th century when the Industrial Revolution of England was initially recognized, the world of learning has been trying to locate the exact causes underneath the dramatic socioeconomic changes. However, all of the relevant studies suffer from major flaws due to various reasons, such as lack of relevant data [106], no criteria available to judge whether or not conjectured variables are scientifically sound and actually working [9], constraint of linear reasoning, and lack of beneficial applications of systemic thinking [8].

Therefore, different from past studies, Forrest et al. [8] employ the methodology of systems science to investigate what underlies successful development of momentum of self-sustained growth for an impoverished agrarian nation. Based on relevant literature and results shown rigorously, these authors develop the following basic procedural steps for an agrarian nation to develop its momentum of self-sustained economic growth.

Step 1: Establish a long-term national goal to become wealthy and powerful.

Step 2: Develop the basic standards of moderate living.

Step 3: Engineer the market fermentation.

Step 4: Promote primary target industries.

Step 5: Successfully round off the first success of developing a self-sustained momentum of economic growth.

By combining this list with what is presented in the previous sections, we can produce the following conclusion: For a well-established economic entity to maintain its current momentum of self-sustained growth, it needs to continuously go through previously listed steps 1, 3, 4, and 5 that are correspondingly modified as follows.

Step A1: Make sure the established long-term goal is still adequate, reflecting the current state of affairs of the world.

Step A2: Continue to ferment new markets for forever-improving and innovative products.

Step A3: Emphasize on most promising endeavors that carry desirable spillover effects on the entire society.

Step A4: Finish off the success of each round of innovative efforts by exploiting the remaining values of current operations and simultaneously by embarking on the next round of exploration.

\section{Conclusions}

The above discussions clearly demonstrate the significance and timeliness of this special issue. By looking at the literature on industrial revolutions, we are quite certain that this issue will not be a sufficiently complete documentary for future generations in the world of learning to draw their 
relevant conclusions on economic developments. Even so, as the editors of this issue, we still hope the articles contained within this issue provide at least some very valuable historical records.

Author Contributions: Both authors of this paper conceptualized the structure of this work. J.Y.-L.F. drafted the first version, while Z.G. finalized the presentation.

Funding: This work received no external funding.

Acknowledgments: We like to use this opportunity to express our sincere thanks to the international journal "Sustainability" for providing us a platform to publish such an important issue on the topic of transition from manufacturing-based development to one that is innovation based. Equally, our sincere appreciation also goes to the numerous editorial assistants who helped process the rigorous, though tedious, peer reviews. Without their editorial support, the eventual and timely publication of this special issue is quite unthinkable. Last, but not the least, our thanks go to the large number of anonymous reviewers from all over the world who went through many rounds of critical reviews and the authors who revised their works again and again until the reviewers' demands were satisfied.

Conflicts of Interest: The authors declare no conflict of interest.

\section{References}

1. Shane, D. Forget the Trade War, China's Economy Has Other Big Problems. CNN Business. Available online: https://www.cnn.com/2018/11/09/economy/china-economy-risks/index.html (accessed on 3 April 2019).

2. Allison, G. Destined for War: Can America and China Escape Thucydides's Trap? Houghton Mifflin Harcourt: Boston, MA, USA, 2017.

3. Fishman, T. China, Inc.: How the Rise of the Next Superpower Challenges America and the World; Scribner: New York, NY, USA, 2006.

4. Clark, G. A Review Essay on the Enlightened Economy: An Economic History of Britain 1700-1850 by Joel Mokyr. J. Econ. Lit. 2012, 50, 85-95. [CrossRef]

5. Allen, R.C. The British Industrial Revolution in Global Perspective; Cambridge University Press: Cambridge, UK, 2009.

6. Acemoglu, D.; Robinson, J. Why Nations Fail-The Origins of Power, Prosperity, and Poverty; The Crown Publishing Group: Danvers, MA, USA, 2012.

7. Clark, G. A Farewell to Alms: A Brief Economic History of the World; Princeton University Press: Princeton, NJ, USA, 2007.

8. Forrest, J.Y.L.; Zhao, H.C.; Shao, L. Engineering rapid industrial revolutions for impoverished agrarian nations. Theor. Econ. Lett. 2018, 8, 2594-2640. [CrossRef]

9. Hartwell, R.M. The Causes of the Industrial Revolution in England; Routledge: London, UK; New York, NY, USA, 2017.

10. Landes, D.S. The Wealth and Poverty of Nations: Why Some Are So Rich and Some So Poor; Norton: New York, NY, USA, 1999.

11. Lucas, R.E. The Industrial Revolution: Past and Future. In Working Paper of Federal Reserve Bank of Minneapolis; Federal Reserve Bank of Minneapolis: Minneapolis, MN, USA, 2003.

12. McCloskey, D.N. Bourgeois Dignity: Why Economics Can't Explain the Modern World; University of Chicago Press: Chicago, IL, USA, 2010.

13. Mokyr, J. The Enlightened Economy: An. Economic History of Britain 1700-1850; Yale University Press: New Haven, CT, USA, 2009.

14. Morris, I. Why the West Rules-for Now: The Patterns of History and What They Reveal about the Future; Profile Books: London, UK, 2010.

15. North, D. Structure and Change in Economic History; Norton: New York, NY, USA, 1981.

16. Pomerranz, K. The Great Divergence: China, Europe, and the Making of the Modern World Economy; Princeton University Press: Princeton, NJ, USA, 2001.

17. Lin, Y.; Forrest, B. Systemic Structure behind Human Organizations: From Civilizations to Individuals; Springer: New York, NY, USA, 2011.

18. Smith, A. The Wealth of Nations; Books I-III; Penguin Books: London, UK, 1776.

19. Michie, J. Introduction. The Internationalisation of the innovation process. Int. J. Econ. Bus. 1998, 5, 261-277. [CrossRef] 
20. Adner, R.; Levinthal, D. Demand heterogeneity and technology evolution: Implications for product and process innovation. Manag. Sci. 2001, 47, 611-628. [CrossRef]

21. Kennedy, S. Made in China 2025: Critical Question. Center for Strategic \& International Studies. Available online: https://www.csis.org/analysis/made-china-2025 (accessed on 3 April 2019).

22. Becheikh, N.; Landry, R.; Amara, N. Lessons from innovation empirical studies in the manufacturing sector: A systematic review of the literature from 1993 to 2003. Technovation 2006, 26, 644-664. [CrossRef]

23. Smith, W.K.; Tushman, M.L. Managing strategic contradictions: A top management model for man-aging innovation streams. Organ. Sci. 2005, 16, 522-536. [CrossRef]

24. Veugelers, R.; Cassiman, B. Make and buy in innovation strategies: Evidence from Belgian manufacturing firms. Res. Policy 1999, 28, 63-80. [CrossRef]

25. Amara, N.; Landry, R. Sources of information as determinants of novelty of innovation in manufacturing firms: Evidence from the 1999 statistics Canada innovation survey. Technovation 2005, 25, 245-259. [CrossRef]

26. Nieto, M.J.; Santamaria, L. The importance of diverse collaborative networks for the novelty of product innovation. Technovation 2007, 27, 367-377. [CrossRef]

27. Alegre, J.; Chiva, R. Assessing the impact of organizational learning capability on product innovation performance: An empirical test. Technovation 2008, 28, 315-326. [CrossRef]

28. Lin, R.J.; Tan, K.H.; Geng, Y. Market demand, green product innovation, and firm performance: Evidence from Vietnam motorcycle industry. J. Clean. Prod. 2013, 40, 101-107. [CrossRef]

29. Caputo, A.; Marzi, G.; Pellegrini, M.M. The internet of things in manufacturing innovation processes: Development and application of a conceptual framework. Bus. Process. Manag. J. 2016, 22, 383-402. [CrossRef]

30. Buffington, J. The future of manufacturing: An end to mass production. In Frictionless Markets; Springer: Berlin, Germany, 2016; pp. 49-65.

31. Zollo, L.; Marzi, G.; Boccardi, A.; Ciappei, C. Gli effetti della Stampa 3D sulla competitivita aziendale. Il caso delle imprese orafe del distretto di Arezzo. Piccola Impresa Small Bus. 2016, 2, 80-100.

32. Roos, G. Servitization as Innovation in Manufacturing: A Review of the Literature. In The Handbook of Service Innovation; Springer: London, UK, 2015; pp. 403-435.

33. Wu, D.; Rosen, D.W.; Wang, L.; Schaefer, D. Cloud-based design and manufacturing: A newparadigm in digital manufacturing and design innovation. Comput. Aided Des. 2015, 59, 1-14. [CrossRef]

34. Schumpeter, J.A. The Theory of Economic Development; Harvard University Press: Cambridge, MA, USA, 1934.

35. Schumpeter, J.A. The process of creative destruction. In Capitalism, Socialism and Democracy, 3rd ed.; Allen and Unwin: London, UK, 1950.

36. Coe, D.T.; Helpman, E. International R\&D spillovers. Eur. Econ. Rev. 1995, 39, 859-887.

37. Engelbrecht, H.J. International R\&D spillovers, human capital and productivity in OECD economies: An empirical investigation. Eur. Econ. Rev. 1997, 41, 1479-1488.

38. Guellec, D.; de la Potterie, B.V.P. The internationalisation of technology analysed with patent data. Res. Policy 2001, 30, 1253-1266. [CrossRef]

39. Brown, S.L.; Eisenhardt, K.M. Product development: Past research, present findings, and future directions. Acad. Manag. Rev. 1995, 20, 343-378. [CrossRef]

40. OECD. The Measurement of Scientific and Technological Activities, Proposed Guidelines for Collecting and Interpreting Technological Innovation Data; Organization for Economic Cooperation and Development: Paris, France, 1997.

41. Ireland, R.D.; Webb, J.W. Strategic entrepreneurship: Creating competitive advantage through streams of innovation. Bus. Horiz. 2007, 50, 49-59. [CrossRef]

42. Pittaway, L.; Robertson, M.; Munir, K.; Denyer, D.; Neely, A. Networking and innovation: A systematic review of the evidence. Int. J. Manag. Rev. 2004, 5, 137-168. [CrossRef]

43. Lansisalmi, H.; Kivimaki, M.; Aalto, P.; Ruoranen, R. Innovation in healthcare: A systematic review of recent research. Nurs. Sci. Q. 2006, 19, 66-72. [CrossRef]

44. Camison-Zornoza, C.; Lapiedra-Alcami, R.; Segarra-Cipres, M.; Boronat-Navarro, M. A metaanalysis of innovation and organizational size. Organ. Stud. 2004, 25, 331-361. [CrossRef]

45. Hobday, M. Firm-level innovation models: Perspectives on research in developed and developing countries. Technol. Anal. Strateg. Manag. 2005, 17, 121-146. [CrossRef]

46. Peres, R.; Muller, E.; Mahajan, V. Innovation diffusion and new product growth models: A critical review and research directions. Int. J. Res. Mark. 2010, 27, 91-106. [CrossRef] 
47. Crossman, M.M.; Apaydin, M. A multi-dimensional framework of organizational innovation: A systematic review of the literature. J. Manag. Stud. 2010, 47, 1154-1191. [CrossRef]

48. Forrest, J.Y.L.; Nightingale, J. Successfully transition into the era of transient competitive advantages. In Proceedings of the 2017 NABET Annual Conference, State College, PA, USA, 26-27 October 2017; pp. 57-79.

49. Zhao, H.C.; Forrest, J.Y.L.; Jirasakuldech, B. A game analysis of trade dumping and antidumping. Theor. Econ. Lett. 2018, 8, 2860-2881.

50. Kam, W.P.; Kiese, M.; Singh, A.; Wong, F. The pattern of innovation in Singapore's manufacturing sector. Singap. Manag. Rev. 2003, 25, 1-34.

51. Quadros, R.; Furtado, A.; Bernardes, R.; Franco, E. Technological innovation in Brazilian industry: An assessment based on the Sao Paulo innovation survey. Technol. Forecast. Soc. Chang. 2001, 67, $203-219$. [CrossRef]

52. Uzun, A. Technological innovation activities in Turkey: The case of manufacturing industry, 1995-1997. Technovation 2001, 21, 189-196. [CrossRef]

53. Baptista, R.; Swann, P. Do firms in clusters innovate more? Res. Policy 1998, 27, 525-540. [CrossRef]

54. Michie, J.; Sheehan, M. Labour market deregulation, 'flexibility' and innovation. Camb. J. Econ. 2003, 27, 123-143. [CrossRef]

55. Zahra, S.A. New product innovation in established companies: Associations with industry and strategy variables. Entrep. Theory Pract. 1993, 18, 47-69. [CrossRef]

56. Blundell, R.; Griffith, R.; Van Reenen, J. Market share, market value and innovation in a panel of British manufacturing firms. Rev. Econ. Stud. 1999, 66, 529-554. [CrossRef]

57. Smolny, W. Determinants of innovation behaviour and investment estimates for West-German manufacturing firms. Econ. Innov. New Technol. 2003, 12, 449-463. [CrossRef]

58. Debackere, K.; Clarysse, B.; Rappa, M.A. Dismantling the ivory tower: The influence of networks on innovative output in emerging technologies. Technol. Forecast. Soc. Chang. 1996, 53, 139-154. [CrossRef]

59. Beneito, P. Choosing among alternative technological strategies: An empirical analysis of formal sources of innovation. Res. Policy 2003, 32, 693-713. [CrossRef]

60. Sternberg, R.; Arndt, O. The firm or the region: What determines the innovation behaviour of European firms? Econ. Geogr. 2001, 77, 364-382. [CrossRef]

61. Romijn, H.; Albaladejo, M. Determinants of innovation capability in small electronics and software firms in southeast England. Res. Policy 2002, 31, 1053-1067. [CrossRef]

62. Beugelsdijk, S.; Cornet, M. 'A far friend is worth more than a good neighbour': Proximity and innovation in a small country. J. Manag. Gov. 2002, 6, 169-188. [CrossRef]

63. Keizer, J.A.; Dijkstra, L.; Halman, J.I.M. Explaining innovative efforts of SMEs. An exploratory survey among SMEs in the mechanical and electrical engineering sector in the Netherlands. Technovation 2002, 22, 1-13. [CrossRef]

64. Morris, M.H.; Avila, R.A.; Allen, J. Individualism and the modern corporation: Implications for innovation and entrepreneurship. J. Manag. 1993, 19, 595-612. [CrossRef]

65. Rhyne, L.C.; Teagarden, M.B.; Van den Panhuyzen, W. Technologybased competitive strategies. The relationship of cultural dimensions to new product innovation. J. High Technol. Manag. Res. 2002, 13, 249-277. [CrossRef]

66. Shane, S. Cultural influences on national rates of innovation. J. Bus. Ventur. 1993, 8, 59-73. [CrossRef]

67. Wu, W.Y.; Chiang, C.Y.; Jiang, J.S. Interrelationships between TMT management styles and organizational innovation. Ind. Manag. Data Syst. 2002, 102, 171-183. [CrossRef]

68. Fritsch, M.; Meschede, M. Product innovation, process innovation, and size. Rev. Ind. Organ. 2001, 19, 335-350. [CrossRef]

69. Koschatzky, K.; Bross, U.; Stanovnik, P. Development and innovation potential in the Slovene manufacturing industry: Analysis of an industrial innovation survey. Technovation 2001, 21, 311-324. [CrossRef]

70. Landry, R.; Amara, N.; Lamari, M. Does social capital determine innovation? To what extent? Technol. Forecast. Soc. Chang. 2002, 69, 681-701. [CrossRef]

71. Ahuja, G.; Katila, R. Technological acquisitions and the innovation performance of acquiring firms: A longitudinal study. Strateg. Manag. J. 2001, 22, 197-220. [CrossRef] 
72. Love, J.H.; Roper, S. Location and network effects on innovation success: Evidence for UK. German and Irish manufacturing plants. Res. Policy 2001, 30, 313-332. [CrossRef]

73. Coombs, R.; Tomlinson, M. Patterns in UK company innovation styles: New evidence from the CBI innovation trends survey. Technol. Anal. Strateg. Manag. 1998, 10, 295-310. [CrossRef]

74. Lanjouw, J.O.; Mody, A. Innovation and the international diffusion of environmentally responsive technology. Res. Policy 1996, 25, 549-571. [CrossRef]

75. Forrest, J.Y.L.; Lin, C.C.; Mondal, S.; Tucker, R. Environmental forces underneath the innovativeness of manufacturing firms. Theor. Econ. Lett. 2019, 9, 1353-1382. [CrossRef]

76. Stock, G.N.; Greis, N.P.; Fischer, W.A. Firm size and dynamic technological innovation. Technovation 2002, 22, 537-549. [CrossRef]

77. Souitaris, V. Technological trajectories as moderators of firm-level determinants of innovation. Res. Policy 2002, 31, 877-898. [CrossRef]

78. Hitt, M.A.; Hoskisson, R.E.; Kim, H. International diversification: Effects on innovation and firm performance in product-diversified firms. Acad. Manag. J. 1997, 40, 767-798.

79. Robertson, P.L.; Langlois, R.N. Innovation, networks, and vertical integration. Res. Policy 1995, $24,543-562$. [CrossRef]

80. Galende, J.; De la Fuente, J.M. Internal factors determining a firm's innovative behaviour. Res. Policy 2003, 32, 715-736. [CrossRef]

81. Porter, M.E. Competitive Strategy: Techniques for Analyzing Industries and Competitors; Free Press: New York, NY, USA, 1980.

82. Malerba, F.; Orsenigo, L.; Peretto, P. Persistence of innovative activities, sectoral patterns of innovation and international technological specialization. Int. J. Ind. Organ. 1997, 15, 801-826. [CrossRef]

83. Hall, L.A.; Bagchi-Sen, S. A study of R\&D, innovation, and business performance in the Canadian biotechnology industry. Technovation 2002, 22, 231-244.

84. Lee, J. Small firms' innovation in two technological settings. Res. Policy 1995, 24, 391-401. [CrossRef]

85. Francois, J.P.; Favre, F.; Negassi, S. Competence and organization: Two drivers of innovation: A micro-econometric study. Econ. Innov. New Technol. 2002, 11, 249-270. [CrossRef]

86. Koeller, C.T. Union membership, market structure, and the innovation output of large and small firms. J. Labour Res. 1996, 17, 683-699. [CrossRef]

87. Baldwin, J.R.; Johnson, J. Business strategies in more- and less-innovative firms in Canada. Res. Policy 1996, 25, 785-804. [CrossRef]

88. Freel, M.S. Sectoral patterns of small firm innovation, networking and proximity. Res. Policy 2003, 32, 751-770. [CrossRef]

89. Forrest, J.Y.L.; Mondal, S.; Tucker, R.; Lin, C.C. Effects of manufacturing firms' strategies on innovation: A holistic view. In Proceedings of the 2018 Annual Conference of NABET, State College, PA, USA, 1-2 November 2018; pp. 74-94.

90. Forrest, J.Y.L.; Tucker, R.; Lin, C.C.; Mondal, S. Impacts of Manufacturing Firms' Culture, Structure and Leadership on Innovation: A Systemic Approach. In Proceedings of the 2018 Annual Conference of NABET, State College, PA, USA, 1-2 November 2018; pp. 95-120.

91. Motwani, J.; Dandridge, T.; Jiang, J.; Soderquist, K. Managing innovation in French small and medium-sized enterprises. J. Small Bus. Manag. 1999, 37, 106-114.

92. Jung, D.I.; Chow, C.; Wu, A. The role of transformational leadership in enhancing organizational innovation: Hypotheses and some preliminary findings. Leadersh. Q. 2003, 14, 525-544. [CrossRef]

93. Chandy, R.K.; Tellis, G.J. Organizing for radical product innovation: The overlooked role of willingness to cannibalize. J. Mark. Res. 1998, 35, 474-487. [CrossRef]

94. Papadakis, V.; Bourantas, D. The chief executive officer as corporate champion of technological innovation: An empirical investigation. Technol. Anal. Strateg. Manag. 1998, 10, 89-98. [CrossRef]

95. Schumpeter, J.A. Capitalism, Socialism and Democracy; Harper: New York, NY, USA, 1942.

96. Tsai, W. Knowledge transfer in intraorganizational networks: Effects of network position and absorptive capacity on business unit innovation and performance. Acad. Manag. J. 2001, 44, 996-1004.

97. Sørensen, J.B.; Stuart, T.E. Aging, obsolescence, and organizational innovation. Adm. Sci. Q. 2000, 45, 81-112. [CrossRef] 
98. Walsh, J.P.; Dewar, R.D. Formalization and the organizational life cycle. J. Manag. Stud. 1987, $24,215-231$. [CrossRef]

99. Darroch, J.; McNaughton, R. Examining the link between knowledge management practices and types of innovation. J. Intellect. Cap. 2002, 3, 210-222. [CrossRef]

100. Koberg, C.S.; Uhlenbruck, N.; Sarason, Y. Facilitators of organizational innovation: The role of life-cycle stage. J. Bus. Ventur. 1996, 11, 133-149. [CrossRef]

101. Gudmundson, D.; Tower, C.B.; Hartman, E.A. Innovation in small businesses: Culture and ownership structure do matter. J. Dev. Entrep. 2003, 8, 1-17.

102. Lukas, B.A.; Ferrell, O.C. The effect of market orientation on product innovation. Acad. Mark. Sci. J. 2000, 28, 239-247. [CrossRef]

103. Parthasarthy, R.; Hammond, J. Product innovation input and outcome: Moderating effects of the innovation process. J. Eng. Technol. Manag. 2002, 19, 75-91. [CrossRef]

104. Sobel, R. When Giants Stumble: Classic Business Blunders and How to Avoid Them; Prentice Hall: Paramus, NJ, USA, 1999.

105. Heaton, H. Industrial revolution. In Encyclopeadia of the Scoial Sciences; and in The Causes of the Industrial Revolution in England; Hartwell, R.M., Ed.; Routledge: London, UK, 2017; Volume VIII, pp. 30-52.

106. Fleischman, R.K.; Parker, L.D. What Is Past Is Prologue: Costing Accounting in the British Industrial Revolution; Routledge: London, UK, 2017; pp. 1760-1850.

(C) 2019 by the authors. Licensee MDPI, Basel, Switzerland. This article is an open access article distributed under the terms and conditions of the Creative Commons Attribution (CC BY) license (http://creativecommons.org/licenses/by/4.0/). 